\title{
Post-Irradiation Morphea: Case report and review of the literature
}

\author{
Ammar Alhathlool, Rüdiger Hein, Christian Andres, Johannes Ring, Bernadette Eberlein \\ Department of Dermatology and Allergy Biederstein, Technische Universität München, Munich, Germany.
}

Corresponding author:

Bernadette Eberlein

Biedersteiner Straße 29

80802 Munich, Germany

E-mail: eberlein@Irz.tum.de

\section{Key words:}

adverse event, radiation, morphea, scleroderma

\begin{abstract}
Background/Purpose: Post-irradiation morphea (PIM) is an entity documented in the literature although still not mentioned in most of the dermatological textbooks with a frequency approximately 2 out of every 1000 patients who received radiotherapy. Most of the cases are misdiagnosed as recurrent or metastatic carcinoma.
\end{abstract}

Main observations: We report on a 64-year-old woman who was treated with radiotherapy for breast cancer. Two years and eight months after the first dose of radiotherapy, she developed localized morphea in the irradiated area.

Conclusion: We report on a new case with a literature review and discuss pathogenesis, treatment modalities and post irradiation subcutaneos reactions mimicking PIM. Around 54 cases of post-irradiation morphea (PIM) were identified in the literature. (J Dermatol Case Rep. 2012; 6(3): 73-77)

\section{Introduction}

Post-irradiation morphea (PIM) is an increasingly recognized condition. In 1905, radiotherapy as trigger factor for morphea was described for the first time, ${ }^{1}$ which was shortly after the discovery of X-rays by Roentgen in 1885 .

In a study, more than $90 \%$ of 203,500 patients undergoing radiotherapy for breast cancer in 2002 developed a degree of radiation-induced skin reaction. ${ }^{2}$ The incidence of localized morphea following radiotherapy appears to be approximately 2 out of every 1000 patients. ${ }^{3}$ In contrast, the incidence of morphea of any etiology is 2.7 per 100000 in the general population per year. ${ }^{4}$

\section{Case Report}

A 64-year-old female presented with 3 lesions at the right breast with yellow-white to ivory-colored and hyperpigmented border with marked hardening of the skin. Since 2007 she complained of erythema at the right breast. Since July 2010 the skin lesions enlarged with hardening of the skin. A breast carcinoma $\mathrm{pT} 1 \mathrm{~cm}$ pTis $\mathrm{Nx} \mathrm{MO}$ had been diagnosed in 2007 and treated with a wide excision. Postoperation treatment consisted of 12 sessions radiotherapy with a total dose of 50.4 Gy (ED 1.8 Gy) and Anastrozole as anti-hormonal therapy. In October 2007, she received the first dose of radiotherapy. During the radiation she developed grade 1 to 2 dermatitis in the irradiated area. In July 2010, she noticed multiple skin lesions at the right breast with induration and tightening of the skin. During the routine followup for breast cancer by a radio-oncologist, a skin biopsy was done which ruled out any malignancy and the patient was referred to us.

By examination, the body mass index BMI was 39. Antinuclear antibodies were weakly positive. Immunoglobulins A, G,M , anti ds-DNA, antibodies against Borrelia burgdorferi, ANCA, Ro,La,Scl-70 antibodies and immunelectrophoresis were all within the normal range.

The biopsy showed a flat epidermis with deep perivascular lymphocyte infiltration with plasma cells. It showed swollen collagen fibers reaching the subcutaneous fat tissue. All of these are consistent with the diagnosis of morphea.

We started the treatment initially with Penicillin 10 Mega intravenously 3 times daily over 14 days combined with UVA1 irradiation (single dose: $50 \mathrm{~J} / \mathrm{cm}^{2}$ ) over 15 days and topical calcipotriol creme (Daivonex ${ }^{\circledR}$ ). We noticed a mild softening of the involved skin during the first month of treatment.

\section{Discussion}

Morphea following radiotherapy has been described under many names in the literature: post-irradiation morphea (PIM), 
radiation-induced morphea (RIM) and radiation port scleroderma. $^{15}$

All the reported cases of post-irradiation morphea (PIM) were female except one male with subcutaneous lymphoma. ${ }^{5}$ Furthermore, morphea of the breast sometimes also occurs in female patients without radiotherapy or breast carcinoma. ${ }^{6}$ It is thought that breast size plays a role in the development of post radiation reactions (PIM or fibrosis). This could be because of dose inhomogeneity or because large breasts have a higher fat content. ${ }^{7}$ Although the association between localized scleroderma and radiotherapy is wellknown, there is still a closer relation between scleroderma and carcinoma. ${ }^{16}$

The 54 reported cases were from different races: african, ${ }^{5}$ $a \operatorname{sian}^{8}$ and caucasian (most patients).

As summarized in Table 1 all - except 7 - cases (54 patients) of post-irradiation morphea (PIM) had breast carcinoma: 4 cases had endocervical and endometrial carcino$\mathrm{ma}^{9-12}$ one case had abdominal aortic aneurysm and was treated with fluoroscopically guided repair of abdominal aortic aneurysm (X-rays with fluorscent screen) which induced post-irradiation morphea (PIM), ${ }^{13}$ one case after chest wall irradiation for subcutaneous lymphoma, ${ }^{5}$ and one with axillary-node irradiation due to adenocarcinoma of unknown origin. ${ }^{9}$

Analyzing the reported cases of PIM, we found an interval between the first radiotherapy dose and the appearance of PIM of 1 month 8 to 32 years. ${ }^{14}$ In the literature few other skin disease associated with PIM were reported such as 2 cases with PIM and lichen sclerosus et atrophicans. ${ }^{18}$ One patient developed PIM with subcutaneous polyarteritis nodosa. ${ }^{17}$

It is believed that systemic sclerosis is a relative risk factor for developing an exaggerated post-irradiation fibrosis. Age and radiotherapy parameters such as total radiation dose, dose per fraction and severity of acute reaction do not seem to be significant risk factors for developing post-irradiation morphea (PIM). ${ }^{3}$

Furthermore radiation induced injury or reactions (dermatitis, edema, etc) involved in the pathogenesis of post-irradiation morphea (PIM) does not appear to be related to the dose of radiation or the severity of the acute tissue reaction to radiation. ${ }^{9}$

The fundamental differences between PIM and RIF (radiation induced fibrosis) are that PIM occurs later in relation to the radiation exposure (mostly 1 month - 3 years or more) compared to RIF, which usually occurs in the first 3 months. There is often an abrupt onset in PIM, with an initial erythema and induration which is not seen in RIF. In addition, histologic findings demonstrate dermal inflammatory infiltrates which are not seen in RIF. ${ }^{14}$ Post-irradiation panniculitis is another recently reported disease in the literature in patients with breast cancer treated with radiation. The first description by Winkelmann of 4 cases in 1993 was followed by additional 4 cases in 2001..$^{19,20}$ These cases were characterized by erythematous indurated plaques in the field of radiation. Biopsies of the affected areas revealed significant changes in the subcutaneous tissues revealing a lobular panniculitis, thickened septae, and an inflammatory infiltrate. The epidermis and dermis were nearly unaffected. ${ }^{20}$
The pathogenesis of PIM is still not completely understood. There are several theories explaining the development of PIM:

1. Radiation-induced neoantigen formation that subsequently stimulates secretion of transforming growth factor beta (TGF- $ß$ ). TGF- $ß$ strongly induces fibroblast activation, collagen synthesis and excessive fibrosis. ${ }^{14-15}$

2. Alteration of the fibroblast population includes an increase of the myofibroblast subset. Radiation affects both fibroblasts and endothelial cells. It induces premature terminal differentiation of fibroblasts to more active forms, which are responsible for the production of collagen and extracellular matrix elements. The normal balance of the fibroblast is disrupted by radiation treatment and this may be a mechanism contributing to the increased collagen production and fibrosis seen in $\mathrm{PIM}^{17}$

The natural history of PIM is poorly described. Skin changes may be improved within few months till few years but the pigmentation usually persists. One patient had improvement without any treatment. ${ }^{14}$

The treatment options are similar to those for idiopathic morphea which includes oral and systemic antibiotics, topical, intralesional and systemic corticosteroids. Multiple treatments for PIM with varying degrees of success have been achieved using topical steroids, ${ }^{6,14,18}$ topical hyaluronidase $^{21}$ and methotrexate. ${ }^{4}$ One patient mildly improved using phonophoresis with hyaluronidase and PUVA bath therapy. ${ }^{21}$ Another case improved with potent topical steroids and showed gradual softening of the involved skin over a 5-year-period but the dermatologist was not convinced that the clinical improvement was therapy related. ${ }^{18}$

In the literature, several studies reported about the effectiveness of the combination treatment of calcipotriol and UVA1 irradiation to treat morphea. ${ }^{22}$ Furthermore, it was shown that the treatment of morphea with UVA1 showed a reduction in sclerotic plaques, an increase in skin elasticity and a reduction of lesional skin thickness. ${ }^{23}$ Another study showed that medium-dose UVA1 in morphea was more effective than narrow-band UVB treatment. ${ }^{24}$ More reports mentioned the effectiveness of Penicillin $\mathrm{G}^{25}$ and topical calcipotriol. ${ }^{26}$

According to all the reported cases, PIM does not appear to be related to the prognosis of the breast cancer.

In our case, we report the first patient with PIM treated with UVA1 irradiation and calcipotriol (Daivonex ${ }^{\circledR}$ ) in addition to Penicillin 10 Mega. We noticed a mild softening of the involved skin during the first month of treatment.

\section{Conclusion}

Although the pathogenesis and the treatment modalities are not completely understood and still have some challenges, PIM should be always considered as radiation complication and must be distinguished from recurrence of malignancy. The diagnosis can only be assured by biopsy. 
Table 1. Report of all post-irradiation morphea published since 1989. Adapted from N. Walsh et al..$^{18}$ and Herrmann ${ }^{27}$ and updated.

\begin{tabular}{|c|c|c|c|c|c|c|}
\hline Study & Cases & Basic disease & $\begin{array}{c}\text { Duration between } \\
\text { 1st radiation and } \\
\text { PIM }\end{array}$ & $\begin{array}{l}\text { Skin disease } \\
\text { beyond } \\
\text { radiation area }\end{array}$ & $\begin{array}{l}\text { Treatment } \\
\text { modalities }\end{array}$ & $\begin{array}{l}\text { Treatment } \\
\text { efficacy }\end{array}$ \\
\hline Colver et al., $1989^{9}$ & 9 & $\begin{array}{c}7 \text { breast Ca.; } \\
1 \text { axilla } \\
\text { (adenocarcinoma } \\
\text { of unknown origin); } \\
1 \text { endocervical } \mathrm{Ca} \text {. }\end{array}$ & $1.5-10 y$ & $4 / 9$ & ND & ND \\
\hline Forbes et al., $1989^{28}$ & 1 & 1 breast Ca. & $<1 \mathrm{y}$ & $1 / 1$ & ND & ND \\
\hline Cooper \& Denham, $1990^{29}$ & 1 & 1 head and neck Ca. & $2 y$ & $0 / 1$ & ND & ND \\
\hline Robertson et al., $1991^{30}$ & 2 & 2 breast Ca. & $<1 \mathrm{y}$ & $1 / 2$ & ND & ND \\
\hline Trattner et al., $1991^{31}$ & 1 & 1 breast Ca. & $<1 \mathrm{y}$ & $1 / 1$ & ND & ND \\
\hline Abu-Shakra et al., $1993^{12}$ & 2 & 1 cervix Ca. & $<1$ y & $0 / 1$ & ND & ND \\
\hline & & 1 head and neck Ca. & $<1 \mathrm{y}$ & $0 / 1$ & ND & ND \\
\hline Winkelmann et al., $1993^{19}$ & 4 & 4 breast $\mathrm{Ca}$. & $<1 \mathrm{y}$ & $0 / 4$ & ND & ND \\
\hline Davis et al., $1996^{15}$ & 6 & 6 breast $\mathrm{Ca}$. & $<1 \mathrm{y}$ & $0 / 6$ & $\begin{array}{c}\text { Topical, } \\
\text { intralesional } \\
\text { and systemic } \\
\text { therapy }\end{array}$ & not effective \\
\hline Mayr et al., $1997^{32}$ & 1 & 1 breast Ca. & $<1 \mathrm{y}$ & $0 / 1$ & ND & ND \\
\hline Smith et al., $1997^{5}$ & 1 & $\begin{array}{l}1 \text { subcutaneous } \\
\text { Iymphoma }\end{array}$ & $3-6 m$ & $0 / 1$ & ND & ND \\
\hline Gollob et al., $1998^{33}$ & 1 & 1 breast Ca. & $<1 \mathrm{y}$ & $0 / 1$ & Topical steroids & ND \\
\hline Bleasel et al., $1999^{3}$ & 4 & 4 breast Ca. & $<1 \mathrm{y}$ & $0 / 4$ & $\begin{array}{l}\text { Topical steroids } \\
\text { under } \\
\text { occlusion for } \\
4-5 \text { months }\end{array}$ & not effective \\
\hline Fischer et al., 199921 & 1 & 1 breast Ca. & $9 y$ & $0 / 1$ & $\begin{array}{c}\text { Phonophoresis } \\
\text { with } \\
\text { Hyaluronidase } \\
\text { and PUVA }\end{array}$ & $\begin{array}{c}\text { Mild } \\
\text { improvement } \\
\text { in the tension } \\
\text { feeling }\end{array}$ \\
\hline Schaffer et al., $2000^{14}$ & 2 & 2 breast $\mathrm{Ca}$. & $6.5-32$ y & $0 / 2$ & $\begin{array}{l}\text { 1st patient with } \\
\text { topical steroids } \\
\text { and oral } \\
\text { doxycyclin } \\
\text { 2nd patient no } \\
\text { treatment }\end{array}$ & $\begin{array}{l}\text { 1st patient } \\
\text { after } 12 \text { mon- } \\
\text { ths normal ap- } \\
\text { pearing skin. } \\
\text { 2nd patient } \\
\text { improvement } \\
\text { after } 9 \text { months }\end{array}$ \\
\hline
\end{tabular}




\begin{tabular}{|c|c|c|c|c|c|c|}
\hline McClelland et al., $2002^{13}$ & 1 & $\begin{array}{l}1 \text { abdominal } \\
\text { aortic } \\
\text { aneurysm }\end{array}$ & ND & ND & ND & ND \\
\hline Ullen \& Björkholm, $2003^{10}$ & 1 & $\begin{array}{l}1 \text { breast and } \\
\text { endometrial Ca. }\end{array}$ & $<1$ and $5 y$ & $1 / 1$ & ND & ND \\
\hline Ardern-Jones \& Black, $2003^{4}$ & 1 & 1 breast Ca. & $13 \mathrm{y}$ & $1 / 1$ & $\begin{array}{l}\text { Methotrexate } \\
2.5 \mathrm{mg} / \mathrm{wk}\end{array}$ & ND \\
\hline Reddy et al., $2005^{17}$ & 1 & 1 breast Ca. & $<1$ y & $1 / 1$ & Prednisolone & $\begin{array}{l}\text { Reduction of } \\
\text { skin changes }\end{array}$ \\
\hline Kim et al., $2005^{8}$ & 1 & 1 breast $C a$. & $1 \mathrm{~m}$ & $0 / 1$ & ND & ND \\
\hline Dancey \& Waters, $2006^{34}$ & 1 & 1 breast $C a$. & $<1 \mathrm{y}$ & $0 / 1$ & ND & ND \\
\hline Dubner et al., $2006^{35}$ & 1 & 1 breast $\mathrm{Ca}$. & $3 y$ & $0 / 1$ & $\begin{array}{l}\text { Mastectomy } \\
\text { refused from } \\
\text { the patient }\end{array}$ & \\
\hline Seale et al., $2008^{36}$ & 1 & 1 breast Ca. & $2 y$ & $0 / 1$ & ND & ND \\
\hline Walsh et al., $2008^{18}$ & 5 & 5 breast $\mathrm{Ca}$. & $4-12$ y & $1 / 5$ & $\begin{array}{l}\text { Potent topical } \\
\text { steroid } \\
\text { other had } \\
\text { mastectomy }\end{array}$ & $\begin{array}{l}\text { Gradual } \\
\text { softening over } \\
\text { a 5-year } \\
\text { period }\end{array}$ \\
\hline Cheah et al., $2008^{37}$ & 1 & 1 breast $\mathrm{Ca}$. & $9 \mathrm{~m}$ & $0 / 1$ & $\begin{array}{l}\text { Topical and } \\
\text { oral steroids } \\
\text { and PUVA }\end{array}$ & not effective \\
\hline Herrmann et al., $2009^{27}$ & 1 & 1 breast Ca. & $1.5 \mathrm{y}$ & $0 / 1$ & ND & ND \\
\hline Akay et al., $2009^{11}$ & 1 & 1 endometrial Ca. & $3.5 \mathrm{y}$ & $1 / 1$ & $\begin{array}{l}\text { Topical steroids } \\
\text { for } 3 \text { months }\end{array}$ & $\begin{array}{l}\text { Partial } \\
\text { response }\end{array}$ \\
\hline Morganroth et al., $2010^{38}$ & 1 & 1 breast Ca. & ND & ND & ND & ND \\
\hline Our case, 2011 & 1 & 1 breast $\mathrm{Ca}$. & $2.7 y$ & $0 / 1$ & $\begin{array}{c}\text { Penicillin, } \\
\text { calcipotriol and } \\
\text { UVA1 }\end{array}$ & $\begin{array}{l}\text { Mild softening } \\
\text { of the involved } \\
\text { skin during } \\
\text { one month }\end{array}$ \\
\hline
\end{tabular}

\section{References}

1. Crocker HR (1905) in: Diseases of the skin. Blakistons, Philadelphia, pp 633.

2. Harper JL, Franklin LE, Jenrette JM, Aguero EG. Skin toxicity during breast irradiation: pathophysiology and management. South Med J. 2004; 97: 989-993. PMID: 15558927.

3. Bleasel NR, Stapleton KM, Commens C, Ahern VA. Radiation-induced localized scleroderma in breast cancer patients. Australas J Dermatol. 1999; 40: 99-102. PMID: 10333622.

4. Ardern-Jones MR, Black MM. Widespread morphea following radiotherapy for carcinoma of the breast. Clinc Exp Dermatol. 2003; 28: 160-162. PMID: 12653704.

5. Smith KJ, Yeager J, Skelton HG. Localized scleroderma in breast cancer patients treated with supervoltage external beam radiation: radiation port scleroderma. J Am Acad Dermatol. 1997; 37: 806-808. PMID: 9366841.

6. Shetty G, Lewis F, Thrush S. Morphea of the breast: case reports and review of literature. Breast J. 2007; 13: 302-304. PMID: 17461908. 
7. Clarke D, Martinez A, Cox RS. Analysis of cosmetic results and complications in patients with stage I and II breast cancer treated by biopsy and irradiation. Int J Radiat Oncol Biol Phys. 1983; 9: 1807-1813. PMID: 6662749.

8. Kim JE, Chong SJ, Park HJ, Oh ST, Lee JY, Cho BK. A case of radiation-induced morphea. Korean J Dermatol. 2005; 43: 826-829.

9. Colver GB, Rodger A, Mortimer PS, Savin JA, Neill SM, Hunter JA. Post-irradiation morphoea. Br J Dermatol. 1989; 120: 831-835. PMID: 2757944.

10. Ullén H, Björkholm E. Localized scleroderma in a woman irradiated at two sites for endometrial and breast carcinoma: a case history and a review of the literature. Int J Gynecol Cancer. 2003; 13: 77-82. PMID: 12631225.

11. Akay BN, Sanli H, Heper AO. Postirradiation linear morphoea. Clin Exp Dermatol. 2010; 35: 106-108. PMID: 19874351.

12. Abu-Shakra M, Guillemin F, Lee P. Cancer in systemic sclerosis. Arthritis Rheum. 1993; 36: 460-464. PMID: 8457221.

13. McClelland M, VanLoock JS, Patterson JW, Greer KE. Radiation-induced morphea occurring after fluoroscopy. J Am Acad Dermatol. 2002; 47: 962-964. PMID: 12451389.

14. Schaffer JV, Carroll C, Dvoretsky I, Huether MJ, Girardi M. Postirradiation morphea of the breast presentation of two cases and review of the literature. Dermatology. 2000; 200: 67-71. PMID: 10681621.

15. Davis DA, Cohen PR, McNeese MD, Duvic M. Localized scleroderma in breast cancer patients treated with supervoltage external beam radiation: radiation port scleroderma. J Am Acad Dermatol. 1996; 35: 923-927. PMID: 8959951.

16. Verbov J. Post-irradiation morphoea. Br J Dermatol. 1989; 121: 819-820. PMID: 2633784.

17. Reddy SM, Pui JC, Gold LI, Mitnick HJ. Postirradiation morphea and subcutaneous polyarteritis nodosa: case report and literature review. Semin Arthritis Rheum. 2005; 34: 728-734. PMID: 15846588.

18. Walsh N, Rheaume D, Barnes P, Tremaine R, Reardon M. Postirradiation morphea: an underrecognized complication of treatment for breast cancer. Hum Pathol. 2008; 39: 1680-1688. PMID: 18656234.

19. Winkelmann RK, Grado GL, Quimby SR, Connolly SM. Pseudosclerodermatous panniculitis after irradiation: an unusual complication of mega voltage treatment of breast cancer. Mayo Clin Proc. 1993; 68: 122-127. PMID: 8423691.

20. Carrasco L, Moreno C, Pastor MA, Izquierdo MJ, Fariña C, Martín L, Sangüeza OP, Requena L. Postirradiation pseudosclerodermatous panniculitis. Am J Dermatopathol. 2001; 23: 283-287. PMID: 11481517.

21. Fischer M, Bormann G, Wohlrab J, Marsch WC. Radiationinduced morphea. Hautarzt. 1999; 50: 507-510. PMID: 10464685.

22. Kreuter A, Gambichler T, Avermaete A, Jansen T, Hoffmann M, Hoffmann K, Altmeyer P, von Kobyletzki G, BacharachBuhles M. Combined treatment with calcipotriol ointment and low-dose ultraviolet A1 phototherapy in childhood morphea. Pediatr Dermatol. 2001; 18: 241-245. PMID: 11438008.

23. Andres C, Kollmar A, Mempel M, Hein R, Ring J, Eberlein B. Successful ultraviolet A1 phototherapy in the treatment of localized scleroderma: a retrospective and prospective study. Br J Dermatol. 2010; 162: 445-447. PMID: 19785603.
24. Kreuter A, Hyun J, Stücker M, Sommer A, Altmeyer P, Gambichler T. A randomized controlled study of low-dose UVA1, medium-dose UVA1 and narrowband UVB phototherapy in the treatment of localized scleroderma. J Am Acad Dermatol. 2006; 54: 440-447. PMID: 16488295.

25. Möhrenschlager M, Jung C, Ring J, Abeck D. Effect of penicillin $\mathrm{G}$ on corium thickness in linear morphea of childhood: An analysis using ultrasound technique. Pediatr Dermatol. 1999; 16: 314-316. PMID: 10469421.

26. Tay YK. Topical calcipotriol ointment in the treatment of morphea. J Dermatolog Treat. 2003; 14: 219-221. PMID: 14660267.

27. Herrmann T, Günther C, Csere P. Localized morphea--a rare but significant secondary complication following breast cancer radiotherapy. Case report and review of the literature on radiation reaction among patients with scleroderma/morphea. Strahlenther Onkol. 2009; 185: 603-607. PMID: 19756427.

28. Forbes AM, Woodrow JC, Verbov JL, Graham RM. Carcinoma of breast and scleroderma: four further cases and literature review. $\mathrm{Br} J$ Rheumatol. 1989; 28: 65-69. PMID: 2537127.

29. Cooper SG, Denham JW. Progressive systemic sclerosis (diffuse scleroderma) and radiotherapy. Br J Radiol. 1990; 63: 804-805. PMID: 2242481.

30. Robertson JM, Clarke DH, Pevzner MM, Matter RC. Breast conservation therapy. Severe breast fibrosis after radiation therapy in patients with collagen vascular disease. Cancer. 1991; 68: 502-508. PMID: 1648431.

31. Trattner A, Figer A, David M, Lurie H, Sandbank M. Circumscribed scleroderma induced by postlumpectomy radiation therapy. Cancer. 1991; 68: 2131-2133. PMID: 1655201.

32. Mayr NA, Riggs CE Jr, Saag KG, Wen BC, Pennington EC, Hussey $\mathrm{DH}$. Mixed connective tissue disease and radiation toxicity. A case report. Cancer. 1997; 79: 612-618. PMID: 9028375.

33. Gollob MH, Dekoven JG, Bell MJ, Assaad D, Rao J. Postradiation morphea. J Rheumatol. 1998; 25: 2267-2269. PMID: 9818675.

34. Dancey AL, Waters RA. Morphea of the breast. Two case reports and discussion of the literature. J Plast Reconstr Aesthet Surg. 2006; 59: 1114-1117. PMID: 16996439.

35. Dubner S, Bovi J, White J, Susnik B. Postirradiation morphea in a breast cancer patient. Breast J. 2006; 12: 173-176. PMID: 16509846.

36. Seale M, Koh W, Henderson M, Drummond R, Cawson J. Imaging surveillance of the breast in a patient diagnosed with scleroderma after breast-conserving surgery and radiotherapy. Breast J. 2008; 14: 379-381. PMID: 18547380.

37. Cheah NL, Wong DW, Chetiyawardana AD. Radiation-induced morphea of the breast: a case report. J Med Case Rep. 2008; 2: 136. PMID: 18447904.

38. Morganroth PA, Dehoratius D, Curry H, Elenitsas R. Postirradiation morphea: A case report with a review of the literature and summary of clinicopathologic differential diagnosis. Am J Dermatopathol. 2010 May 24. [Epub ahead of print]. PMID: 20520527. 